\title{
Comparative Pedagogical Analysis of Teacher Education Programs in France And The USA
}

\author{
Evgenii A. Alisov ${ }^{1 *}$, Nikolay A. Podymov ${ }^{2}$, Vladimir M. Postavnev ${ }^{1}$, Irina V. Postavneva ${ }^{1}$, \\ and Yaroslava N. Ospanova ${ }^{3}$ \\ ${ }^{1}$ Moscow City University, Institute of Pedagogics and Psychology of Education, Department of \\ Pedagogics, Moscow, Russia \\ ${ }^{2}$ Moscow State Pedagogical University, Chair of Educational Psychology, Faculty of Pedagogics and \\ Psychology, Moscow, Russia \\ ${ }^{3}$ Eurasian Humanities Institute, Nur-Sultan, Kazakhstan
}

\begin{abstract}
This article presents the results of comparative pedagogical studies that aim at determining the general and specific features of teacher education programs in France and the US. The study is based on binary comparisons and classical methods of comparative pedagogy, including comparative, descriptive and inductive-deductive. In the course of the study, the authors of the article determined conditions for efficient teacher training that are common to the French and US systems of higher education; established the key factor causing the specific functioning of education systems in France and the US; indicated the priority directions of designing teacher education programs in France and the US. The authors have interpreted the study results with due regard to the competency-based educational paradigm and determined trends that condition the general laws of designing educational programs.
\end{abstract}

\section{Introduction}

The comparative pedagogical research of higher pedagogical education is relevant since it searches for the most effective guidelines in training a successful teacher $[1,2]$. The French and US education systems are characterized by their years-long experience in compiling and implementing educational programs, whose enrichment will update and reform education systems in other countries. To achieve the study objective and determine the general and specific rules for designing teacher education programs in France and the US, we also need to solve the following tasks:

1) To determine conditions for efficient teacher training that are common to the French and US systems of higher education;

2) To establish the key factor causing the specific functioning of education systems in France and the US;

3) To indicate the priority directions of designing teacher education programs in France and the US.

\footnotetext{
* Corresponding author: alisove@mgpu.ru
} 


\section{Methods}

In general, the study is based on binary comparisons, where both education systems are foreign for the Russian authors. This type of research ensures the independent position of scholars ("external observers"). The main scientific method was comparison (typical of comparative studies [3]) used to identify the similarities and differences in teacher education programs in France and the US. Comparison (according to the criteria indicated in the abovementioned tasks) comprised two specific educational programs for teacher training $[4,5]$. The descriptive method was used to determine the general conditions for the effective professional training of future teachers since the data obtained in the process of the study should be systematized based on the in-depth interpretation of emerging patterns. The inductive-deductive method helped to establish the key factor determining the specific functioning of education systems in France and the US.

\section{Results}

Common conditions for the effective professional training of teachers in France and the US are as follows:

- The professional and pedagogical motivation of students (there are quite strict requirements for applicants, i.e. not only the level of their knowledge but also their personality traits are taken into account);

- The comprehensive nature and systematic organization of higher education, which implies the integration of invariant and variable components of educational programs, as well as focus on the formation of a moral culture, information literacy, global thinking and active citizenship;

- Equal rights and opportunities for different categories of students (having various health capabilities, ethnicity, religion, social status);

- The practice-oriented nature of psychological and pedagogical training using modern objective means of assessing the quality of education;

- More academic hours for teaching internship to let students "immerse" into the real-life educational process.

In the context of education management, the key factor determining the specific functioning of a certain education system is the type of management: centralized (France) and decentralized (the US).

The priority directions of designing teacher education programs in France are the following types of professional pedagogical activities: close interaction with pupils and their parents, the consideration of specific developmental disorders and contribution to the functioning of child-care facilities. In the US education system, these professional pedagogical activities include planning, preparing and creating an emotional, developing and safe educational environment; the organization of educational processes; self-development and self-improvement.

\section{Discussion}

The study results testify that teacher education programs designed in France and the US comply with the competency-based educational paradigm that highlights the need to form "future competences" [6]. If we conduct a further comparison of these systems, we need to state that the French educational programs are more focused on competences than the ones developed in the US. Thus, the competency-based model of the French graduate who obtained a pedagogical specialty includes the following five groups of competences: 
- Competences related planning and forming education space; comparing the pedagogical potential of various educational methods, means, forms and techniques; ensuring the psychological comfort and safety of pupils;

- Competences related to the manifestation of an individual approach and empathic subjective attitude to each child; the implementation of pedagogical support and assistance; the consideration of pupils' typological characteristics; the implementation of different approaches to the organization of educational processes;

- Competences related to the practical application of modern scientific and pedagogical knowledge; the introduction of innovative educational technologies; planning the educational process based on interdisciplinary and metasubject principles; ensuring the integrated and uniform implementation of standard educational programs; taking into account the dynamic educational needs of pupils;

- Competences related to the influence of socio-cultural determinants of professional pedagogical activity; ensuring effective communication with parents; the use of advanced pedagogical experience in their own activities; establishing constructive relationships with colleagues in the pedagogical community;

- Competences related to the subjective understanding of the problems and prospects typical of professional pedagogical activity and professional reflection; the search and substantiation of the axiological and substantive foundations of pedagogical ideals; pedagogical experimentation; providing the praxeological effect of pedagogical activity.

Both French [7] and Russian [8] scholars confirm that the French teacher education programs focus on the formation of the above-mentioned competences. In general, the French educational programs are characterized by more distinctive specialization. They update the principle of multifunctionality, the "non-pedagogical" component of training, the application of problem-based teaching methods, the development of students' critical thinking (which corresponds to global trends in the development of education $[9,10])$.

Although the management of the US education system is decentralized and states have different teacher education programs, the planned results of mastering such programs also imply the formation of professional pedagogical competences. Based on competence components, many US educational programs for teacher training [4] indicate that a graduate should have the following capabilities:

- Knowledge: the regulatory framework of educational activities both in a particular state and in the country as a whole; the age-related and individual development of pupils; the main directions of training and education;

- Skills: to hold student activities; select and develop diagnostic tools; to monitor and study the behavior of children, record and interpret its manifestations; to consider personality traits and draw up individual development plans for different groups of children; to carry out the psychological and pedagogical correction of certain behavioral patterns; to form a psychologically comfortable and safe educational environment; to help children experience positive emotions;

- Abilities: methodological techniques for organizing work with students; methods of active learning and parenting; techniques for interacting with pupils; verbal and non-verbal means of communication with children; valid diagnostic tools to determine the level of children's development; ways to involve parents into educational activities, etc.

The US teacher education programs are characterized by a greater practical orientation [11] (which is required in the current socio-economic conditions [12]) and different techniques for organizing the educational process.

The common features of teacher education programs in France and the US are aligned with the modernization of pedagogical education in Russia that should make the existing educational space more flexible, creative, accessible, mobile and safe $[13,14,15]$ in accordance with the principles of natural [16] and cultural conformity [17]. 


\section{Conclusion}

This study has revealed several trends that determine the general laws of designing teacher education programs in France and the USA:

- To strengthen the severity of selecting applicants to pedagogical training programs;

- To combine pedagogical, psychological and sociological components of teacher training;

- To update the existing technologies and methods for training teachers (i.e. to increase the number of productive and interactive methods);

- To encourage students' cognitive and creative activities, as well as form their pedagogical thinking (through the use of personality-oriented pedagogical technologies);

- To develop concentration programs (including those determined by the age of future students);

- To improve the organization and realization of teaching internship;

- To promote higher pedagogical education among an absolute majority of teachers.

Each of the indicated trends might become the subject matter of specific studies in the field of comparative pedagogy.

\section{References}

1. I.Burić, A. Moè. What makes teachers enthusiastic: The interplay of positive affect, self-efficacy and job satisfaction. Teaching and Teacher Education 89 (2020)

2. A.M. Spear, R.B. da Costa. Potential for transformation? Two teacher training programs examined through a critical pedagogy framework. Teaching and Teacher Education 69 202-209 (2018)

3. A. Clarke, J. Mena. An international comparative study of practicum mentors: Learning about ourselves by learning about others. Teaching and Teacher Education 90 (2020)

4. Early Childhood Teacher Education Program (Illinois State University, 2012)

5. Programmes d'enseignement du cycle des apprentissages fondamentaux, du cycle de consolidation et du cycle des approfondissements. Bulletin officiel special 11 (2015)

6. S.A. Averin, E.A. Alisov, N.S. Murodkhodzhaeva, I.A. Noskov, O.V. Tsaplina, L.E. Osipenko. Information Technologies in Education: Forming the Competences of the Future. International Journal of Engineering and Technology (UAE) 4.7(7) 276-282 (2018)

7. V. Grosstephan. Accompagner la mastérisation de la formation des enseignants en France: undispositif de régulation pour les formateurs des IUFM. Questions Vives 24 (2015)

8. Yu.S. Ostrovaya, "Practical orientation of the training of future teachers in France". Aktualnyye problemy gumanitarnykh i yestestvennykh nauk 9(1) 213-216 (2016)

9. V.L. Barth, V. Piwowar, I.R. Kumschick, D. Ophardt, F. Thiel. The impact of direct instruction in a problem-based learning setting. Effects of a video-based training program to foster preservice teachers' professional vision of critical incidents in the classroom. International Journal of Educational Research 95 1-12 (2019)

10. E.M. Janssen, T. Mainhard, R.S.M. Buisman, P.P.J.L. Verkoeijen, T. van Gog. Training higher education teachers' critical thinking and attitudes towards teaching it. Contemporary Educational Psychology 58 310-322 (2019) 
11. A.M. Sidorkin. Teacher Training in the United States: Lessons for Russia. Voprosy obrazovaniya 1 136-156 (2013)

12. P. Sztajn, D.J. Heck, K.A. Malzahn and L.K. Dick. Decomposing practice in teacher professional development: Examining sequences of learning activities. Teaching and Teacher Education 9 (2020)

13. S.S. Chesak, T.K. Khalsa, A. Bhagra, S.M. Jenkins, Amit Sood. Stress Management and Resiliency Training for public school teachers and staff: A novel intervention to enhance resilience and positively impact student interactions. Complementary Therapies in Clinical Practice 37 32-38 (2019)

14. L.S. Podymova, N.A. Podymov, E.A. Alisov, Integration of Education 4(22), 663-680 (2018)

15. M. Taylor, L. McLean, C.I. Bryce, T. Abry, K.L. Granger, Teaching and Teacher Education 86, (2019)

16. E.A. Alisov, E.I. Cherdymova, G.F. Trubina, A.N. Yakushev, S.P. Zhdanov, O.V. Popova, M.N. Kobzar-Frolova, Ekoloji 27(106), 357-362 (2018)

17. S. Civitillo, L.P. Juang, M.K. Schachner, Educational Research Review 24, 67-83 (2018) 